\title{
Hubungan antara Gigi Berjejal dan Status Gizi pada Remaja
}

\author{
Agnes M. Andries, Pritartha S. Anindita, Paulina N. Gunawan
}

\author{
Program Studi Pendidikan Dokter Gigi Fakultas Kedokteran Universitas Sam Ratulangi, \\ Manado, Sulawesi Utara, Indonesia \\ Email: agnesmandries@gmail.com
}

\begin{abstract}
Malocclusion is one of the most common dental and oral health problems after caries and periodontal disease. Most of the malocclusions occur in adolescence and manifest as crowding teeth. Malnutrition can inhibit the growth and development of the skull and jaw bones, therefore, the permanent teeth have lack space to erupt resulting in crowding teeth. This study was aimed to determine the relationship between crowding teeth and nutritional status among adolescents in Indonesia. This was a literature review study using three databases, Google Scholar, GARUDA, and Pubmed. Keywords used were crowding, malocclusion, malnutrition, adolescent, Height for Index, BMI, nutritional status, adolescents. After being selected based on inclusion and exclusion criteria, a critical appraisal was carried out and obtained 8 cross-sectional study literatures. The review showed that there were more literatures stating that there was no relationship between crowding teeth and nutritional status among adolescents. Apart from nutritional status, there were several other factors that could affect crowding teeth in adolescents such as bad habits, history of crowding deciduous teeth, heredity, and socioeconomic status. In conclusion, crowding teeth in adolescents is influenced by nutritional status as well as other factors
\end{abstract}

Keywords: crowding, nutritional status, adolescents.

\begin{abstract}
Abstrak: Maloklusi telah menjadi salah satu permasalahan kesehatan gigi dan mulut yang sering dijumpai setelah karies dan penyakit periodontal. Sebagian besar maloklusi terjadi pada usia remaja dalam bentuk gigi berjejal. Status gizi yang kurang dapat menghambat pertumbuhan dan perkembangan tulang tengkorak maupun rahang yang menyebabkan gigi permanen kekurangan ruang untuk erupsi dan terjadi gigi berjejal. Penelitian ini bertujuan untuk mengetahui hubungan gigi berjejal dan status gizi pada remaja di Indonesia. Jenis penelitian ialah literature review dengan pencarian data menggunakan tiga database yaitu Google Scholar, GARUDA, dan Pubmed. Kata kunci yang digunakan yaitu crowding, malocclusion, malnutrition, BMI, adolescent, maloklusi, TB/U, IMT, Status Gizi, Remaja. Setelah diseleksi berdasarkan kriteria inklusi dan ekslusi, dilakukan critical appraisal dan didapatkan 8 literatur cross-sectional study. Hasil kajian menunjukkan terdapat lebih banyak literatur yang menyatakan tidak terdapat hubungan antara gigi berjejal dan status gizi pada remaja. Selain status gizi, faktor lainnya yang dapat memengaruhi terjadinya gigi berjejal pada remaja ialah kebiasaan buruk, riwayat gigi desidui berjejal, keturunan, dan status sosial ekonomi orang tua.. Simpulan penelitian ini ialah gigi berjejal pada remaja tidak hanya dipengaruhi oleh status gizi saja namun dapat disebabkan oleh faktor lain juga.
\end{abstract}

Kata kunci: gigi berjejal, status gizi, remaja

\section{PENDAHULUAN}

Kelainan susunan gigi atau maloklusi menjadi salah satu permasalahan kesehatan gigi dan mulut yang masih sering dijumpai setelah karies dan penyakit periodontal. Sebagian besar maloklusi terjadi pada usia remaja dengan tingkat keparahan yang berbeda-beda. Maloklusi dapat memicu masalah kesehatan yang lain pada rongga mulut, terlebih dapat menimbulkan ketidakpercayaan diri pada remaja akibat kondisi gigi yang tidak teratur. ${ }^{1}$ 
Terdapat beberapa bentuk umum maloklusi diantaranya berupa crowding, deepbite, crossbite, spacing, maupun openbite. ${ }^{2}$ Crowding atau gigi berjejal merupakan bentuk maloklusi yang paling sering terjadi pada remaja. ${ }^{3}$ Penelitian yang dilakukan Wijanarko ${ }^{4}$ di Jakarta tahun 1999 menyatakan dari 270 sampel pada anak berusia 12-14 tahun diperoleh gigi berjejal (dental crowding) sebesar 44,9\%. ${ }^{4}$ Penelitian lain oleh Feroza et al $^{5}$ di Banjarbaru tahun 2017 pada anak berusia 1318 tahun menunjukkan prevalensi crowding anterior pada 60 sampel sebesar $61 \%$.

Tingkat keparahan gigi berjejal yang dimiliki tiap individu tentunya berbeda dari ringan ke berat. Umumnya, penentuan gigi berjejal diklasifikasikan berdasarkan derajat keparahan yang dikemukakan oleh Proffit. Klasifikasi ini dibutuhkan untuk mengelompokkan bentuk penyimpangan tersebut dalam kategori yang lebih kecil. ${ }^{6}$

Gigi berjejal yang terjadi pada remaja umumnya sudah terdiagnosis pada usia 1214 tahun, karena pada usia tersebut diperkirakan gigi permanen telah tumbuh lengkap sejumlah 28 gigi sampai pada gigi molar kedua di masing-masing kuadran. ${ }^{7}$ Usia tersebut masuk dalam kategori remaja awal, seperti ketetapan WHO yaitu usia 10-14 tahun sebagai remaja awal dan 15-20 tahun sebagai remaja akhir. ${ }^{8}$

Bagi remaja, keadaan gigi yang tidak teratur sangat berpengaruh pada estetika tampilan wajah, sehingga dapat menyebabkan kurangnya kepercayaan diri seseorang dan masalah psikologi yang cukup serius. Gigi berjejal yang tidak segera dirawat juga mengakibatkan gangguan dan hambatan. Beberapa dampaknya antara lain gangguan sendi temporomandibular, kesulitan dalam berbicara, peningkatan resiko karies, dan penyakit periodontal. $^{9}$

Tidak jauh berbeda dengan maloklusi, gizi juga masih menjadi masalah yang dihadapi dunia termasuk di Indonesia. Saat ini, Indonesia menghadapi masalah gizi ganda, yaitu gizi kurang dan gizi berlebih. Kurangnya persediaan pangan, kemiskinan, sanitasi, pengetahuan masyarakat tentang gizi, menu seimbang dan kesehatan merupa- kan penyebab umum masalah gizi. ${ }^{10}$ Status gizi merupakan keadaan kesehatan tubuh seseorang yang diakibatkan oleh konsumsi, penyerapan dan penggunaan zat-zat gizi makanan, dimana hal tersebut menjadi salah satu indikator derajat kesehatan. Untuk menilai status gizi pada seseorang dapat diukur menggunakan antropometri. Beberapa pengukuran antropometri yang sering dilakukan yaitu Indeks BB/U, TB/U, BB/TB dan Body Mass Index (BMI) / Indeks Massa Tubuh (IMT). Hasil dari nilai antropometri dapat dikategorikan seseorang tersebut dalam status gizi normal atau tidak normal. ${ }^{10}$

Gizi juga diketahui menjadi salah satu faktor yang dapat menyebabkan gigi berjejal. Kecukupan gizi dalam masa pertumbuhan sangat berkaitan dengan proses pertumbuhan dan perkembangan tubuh secara umum, khususnya pada rongga mulut. Ketidakseimbangan gizi atau biasa disebut malnutrisi dapat mengakibatkan tumbuh kembang yang terhambat, sehingga pada rongga mulut, asupan gizi yang adekuat sangat diperlukan. ${ }^{11}$

Pertumbuhan dan perkembangan rahang pada saat remaja sangat dipengaruhi oleh asupan gizi pada masa tumbuh kembang anak. Asupan gizi yang tidak sesuai dapat menyebabkan terjadinya malnutrisi yang dapat memengaruhi pembentukan dan pertumbuhan rahang serta tulang wajah. Seseorang yang memiliki nutrisi atau gizi kurang dari yang dibutuhkan oleh tubuhnya akan mengalami pertumbuhan dan perkembangan dari tulang tengkorak maupun rahang lebih lambat daripada yang memiliki asupan gizi cukup. Keadaan tersebut menyebabkan gigi permanen kekurangan ruang untuk erupsi sehingga gigi berjejal. ${ }^{12}$

Sejalan dengan pernyataan sebelumnya, penelitian yang dilakukan oleh Dermawan et $\mathrm{al}^{13}$ di Padang tahun 2016 pada anak usia 1214 tahun diperoleh hasil 97,1\% meng-alami malnutrisi disertai gigi berjejal. Berdasarkan hasil penelitian tersebut dapat diungkapkan bahwa gizi memiliki pengaruh terhadap kejadian gigi berjejal pada remaja. ${ }^{13}$ Keterkaitan antara gigi berjejal dan status gizi pada remaja mendorong penulis untuk lebih lanjut membahas dan menelaah ber- 
bagai informasi ilmiah mengenai gigi berjejal dan status gizi pada remaja.

\section{METODE PENELITIAN}

Penelitian ini berbentuk literature review dan dilakukan pada bulan Oktober-Desember 2020. Data yang digunakan dalam penelitian ini diperoleh dari tiga database dengan kriteria yang ditentukan yaitu Pubmed, GARUDA dan Google Scholar. Kata kunci yang digunakan dalam pencarian artikel yaitu gigi berjejal, maloklusi, TB/U, IMT, status gizi, remaja, crowding, malocclusion, malnutrition, BMI, adolescent. Kriteria inklusi penelitian ini yakni: populasi remaja yang melewati periode gigi bercampur 12-15 tahun. outcomes kaitan gigi berjejal dengan status gizi remaja, jenis penelitian crosssectonal study, longitudinal study, tahun publikasi 2010 sampai 2019 berbahasa inggris dan Indonesia. Kriteria ekslusi yakni artikel tidak tersedia fulltext.

\section{HASIL PENELITIAN}

Berdasarkan hasil pencarian literatur didapatkan sebanyak 54 literatur yang menggunakan PubMed, 181 menggunakan GARUDA, 217 menggunakan Google Scholar $(\mathrm{n}=452)$ yang sesuai dengan kata kunci tersebut. Hasil pencarian yang sudah didapatkan kemudian dilakukan skrining berdasarkan judul yang sesuai dengan tema literature review dan didapatkan 26 artikel $(n=26)$. Selanjutnya 26 artikel tersebut diskrining abstrak dan fulltext berdasarkan kriteria inklusi dan ekslusi dan didapatkan 8 artikel $(\mathrm{n}=8)$ yang memenuhi kriteria kelayakan untuk digunakan dalam penelitian literature review ini.

Tabel 1 memperlihatkan hasil kajian dari delapan literatur yang dipakai dalam penelitian ini. Terdapat tujuh literatur yang berasal dari Indonesia dan satu artikel berasal dari luar Indonesia, yaitu Salvador sebagai pembanding.

\section{BAHASAN}

Hasil kajian literatur yang diperoleh memperlihatkan bahwa lebih banyak ditemukan penelitian dengan hasil tidak terdapat hubungan antara gigi berjejal dan status gizi pada remaja, dibandingkan yang menyatakan adanya hubungan antara gigi berjejal dan status gizi pada remaja. Di antaranya ialah penelitian oleh Erliera dan Alamsyah ${ }^{14}$ tahun 2015 di Kecamatan Medan Baru, yang menyatakan kasus gigi berjejal paling banyak yaitu $51,91 \%$ pada status gizi normal dan tidak terdapat hubungan bermakna antara status gizi dengan kasus gigi berjejal melalui uji chi-square dengan hasil $\mathrm{p}=0,750$. Menggunakan uji statistik yang sama, penelitian oleh Jufri et al $^{16}$ tahun 2018 menunjukkan nilai signifikansi sebesar 0,241 ( $>0,05)$ dengan kesimpulan tidak terdapat hubungan antara status gizi dengan tingkat keparahan maloklusi.

Hasil penelitian yang serupa dengan penggunaan uji statistik yang berbeda juga didapatkan pada penelitian Pristarani ${ }^{18}$ tahun 2017 di Yogyakarta, melalui uji korelasi Kendall's Tau_b nilai (Sig) >0,05 yaitu $\mathrm{Sig}=0,241>0,05$ yang menunjukkan bahwa tidak terdapat hubungan bermakna. Hasil tersebut juga selaras dengan penelitian oleh Wibawa ${ }^{19}$ tahun 2017 yang mendapatkan hasil Sig. 0,405; angka tersebut menunjukkan bahwa tidak terdapat hubungan yang bermakna. Kemungkinan terjadinya gigi berjejal atau maloklusi dikarenakan oleh faktor lain dan tidak hanya disebabkan oleh status gizi saja.

Terjadinya gigi berjejal atau maloklusi pada seseorang memiliki faktor penyebab yang multifaktorial. Karies pada gigi desidui dan ekstraksi gigi molar desidui, dapat memicu terjadinya migrasi gigi premolar pertama, inklinasi, dan rotasi sehingga menyebabkan maloklusi. ${ }^{21}$ Selain itu, Proffit juga berpendapat bahwa erupsi gigi molar tiga dapat mempengaruhi terjadinya maloklusi. Hal ini disebabkan karena mayoritas orang mengalami impaksi gigi molar ketiga diakibatkan oleh ketersediaan rahang yang terbatas. ${ }^{22}$ Ukuran dan jumlah gigi juga dapat menjadi faktor lokal penyebab gigi berjejal. Sejalan dengan penelitian yang dilakukan oleh Poosti ${ }^{23}$ tahun 2007 yang menyebutkan bahwa terdapat pengaruh antara ukuran gigi dengan terjadinya kasus gigi berjejal; hal ini dilihat dari hasil penelitian pada responden dengan 
Tabel 1. Hasil kajian literatur yang dipakai dalam penelitian ini

\begin{tabular}{|c|c|c|c|c|c|}
\hline No. & $\begin{array}{c}\text { Peneliti / } \\
\text { Tahun }\end{array}$ & $\begin{array}{c}\text { Lokasi } \\
\text { penelitian }\end{array}$ & Judul penelitian & $\begin{array}{l}\text { Metode / } \\
\text { Sampel }\end{array}$ & Hasil penelitian \\
\hline 1. & $\begin{array}{l}\text { Erliera et } \\
\text { al. }{ }^{14}(2015)\end{array}$ & $\begin{array}{l}\text { Medan } \\
\text { Baru }\end{array}$ & $\begin{array}{l}\text { Hubungan status gizi } \\
\text { dengan kasus gigi } \\
\text { berjejal pada murid } \\
\text { SMP kecamatan Medan } \\
\text { Baru }\end{array}$ & $\begin{array}{l}\text { Cross- } \\
\text { sectional } \\
\text { study / } \\
180 \text { orang }\end{array}$ & $\begin{array}{l}\text { Tidak terdapat hubungan } \\
\text { antara status gizi dan gigi } \\
\text { berjejal pada siswa SMP } \\
\text { kecamatan Medan Baru. }\end{array}$ \\
\hline 2. & $\begin{array}{l}\text { Dermawan } \\
\text { et al. }{ }^{13} \\
(2016)\end{array}$ & Padang & $\begin{array}{l}\text { Hubungan status gizi } \\
\text { terhadap kesejajaran } \\
\text { gigi anterior mandibula } \\
\text { berdasarkan } \\
\text { pengukuran LII pada } \\
\text { siswa SMPN } 5 \text { Padang }\end{array}$ & $\begin{array}{l}\text { Cross- } \\
\text { sectional } \\
\text { study / } \\
60 \text { orang }\end{array}$ & $\begin{array}{l}\text { Terdapat hubungan yang } \\
\text { signifikan antara status gizi } \\
\text { dengan kesejajaran gigi } \\
\text { anterior mandibula. }\end{array}$ \\
\hline 3. & $\begin{array}{l}\text { Thomaz et } \\
\text { al. }{ }^{15}(2010)\end{array}$ & Salvador & $\begin{array}{l}\text { Is Malnutrition } \\
\text { Associated with } \\
\text { Crowding in Permanent } \\
\text { Dentition? }\end{array}$ & $\begin{array}{l}\text { Cross- } \\
\text { sectional } \\
\text { study / } \\
2.060 \text { orang }\end{array}$ & $\begin{array}{l}\text { Terdapat hubungan antara } \\
\text { status gizi \& gigi berjejal } \\
\text { pada remaja dengan } \\
\text { kebiasaan bernafas melalui } \\
\text { mulut. }\end{array}$ \\
\hline 4. & $\begin{array}{l}\text { Jufri et al. }{ }^{16} \\
(2018)\end{array}$ & Makassar & $\begin{array}{lr}\text { Hubungan } & \text { status gizi } \\
\text { dengan } & \text { tingkat } \\
\text { keparahan } & \text { maloklusi } \\
\text { pada pelajar usia } 14-15 \\
\text { tahun }\end{array}$ & $\begin{array}{l}\text { Cross- } \\
\text { sectional } \\
\text { study / } \\
66 \text { orang }\end{array}$ & $\begin{array}{l}\text { Tidak terdapat hubungan } \\
\text { antara status gizi dengan } \\
\text { tingkat keparahan maloklusi } \\
\text { pada pelajar usia } 14-15 \\
\text { tahun SMPN } 27 \text { Makassar. }\end{array}$ \\
\hline 5. & $\begin{array}{l}\text { Oktasafitri } \\
\text { et al. }{ }^{17} \\
(2014)\end{array}$ & Medan & $\begin{array}{l}\text { Hubungan status gizi } \\
\text { dengan gigi berjejal } \\
\text { pada murid SMP } \\
\text { Sutomo } 2 \text { Medan }\end{array}$ & $\begin{array}{l}\text { Cross- } \\
\text { sectional } \\
\text { study / } \\
80 \text { orang }\end{array}$ & $\begin{array}{l}\text { Terdapat hubungan yang } \\
\text { signifikan antara status gizi } \\
\text { dengan gigi berjejal. }\end{array}$ \\
\hline 6. & $\begin{array}{l}\text { Pristarani et } \\
\text { al. }{ }^{18}(2017)\end{array}$ & Yogyakarta & $\begin{array}{l}\text { Hubungan indeks } \\
\text { massa tubuh dengan } \\
\text { maloklusi } \\
\text { menggunakan (DAI) }\end{array}$ & $\begin{array}{l}\text { Cross- } \\
\text { sectional } \\
\text { study / } \\
37 \text { orang }\end{array}$ & $\begin{array}{l}\text { Tidak terdapat hubungan } \\
\text { antara IMT dengan maloklusi }\end{array}$ \\
\hline 7. & $\begin{array}{l}\text { Wibawa et } \\
\text { al. }{ }^{19}(2017)\end{array}$ & Yogyakarta & $\begin{array}{l}\text { Hubungan indeks massa } \\
\text { tubuh dengan maloklusi } \\
\text { menggunakan (HMAI) }\end{array}$ & $\begin{array}{l}\text { Cross- } \\
\text { sectional } \\
\text { study / } \\
37 \text { orang }\end{array}$ & $\begin{array}{l}\text { Tidak terdapat hubungan } \\
\text { antara IMT dengan maloklusi }\end{array}$ \\
\hline 8. & $\begin{array}{l}\text { Falasifah et } \\
\text { al. }{ }^{20}(2017)\end{array}$ & Yogyakarta & $\begin{array}{l}\text { Hubungan indeks massa } \\
\text { tubuh dengan maloklusi } \\
\text { menggunakan (OFI) }\end{array}$ & $\begin{array}{l}\text { Cross- } \\
\text { sectional } \\
\text { study / } \\
37 \text { orang }\end{array}$ & $\begin{array}{l}\text { Tidak terdapat hubungan } \\
\text { antara IMT dengan maloklusi }\end{array}$ \\
\hline
\end{tabular}

kasus gigi berjejal terdapat ukuran gigi yang lebih besar dibandingkan pada responden dengan gigi yang tidak berjejal.

Penelitian oleh Falasifah ${ }^{20}$ di tahun 2017 juga tidak mendapatkan hubungan terkait maloklusi dan status gizi pada remaja usia 13-15 tahun. Peneliti melakukan anamnesis pada subjek penelitian terkait kemungkinan adanya faktor lain yang dapat menyebabkan maloklusi. Berdasarkan hasil jawaban dari pertanyaan anamnesis, faktor lain penyebab maloklusi terbanyak yaitu riwayat gigi desidui rapat atau berjejal sebanyak
$81,1 \%$. Hasil tersebut didukung oleh penelitian Vinay et al ${ }^{24}$ tahun 2011 yang menyatakan bahwa anak dengan gigi desidui yang mengalami spacing atau renggang memiliki kemungkinan yang lebih rendah untuk mengalami maloklusi pada periode gigi permanen sementara anak-anak dengan gigi desidui yang rapat memiliki frekuensi yang lebih tinggi dalam mengalami maloklusi.

Pertanyaan anamnesis terkait penyebab maloklusi juga dilakukan pada penelitian Wibawa $^{19}$ tahun 2017. Pada lembar pertanyaan dituliskan "Apakah orang tua atau 
keluarga anda memiliki kondisi gigi geligi yang sama dengan anda?". Berdasarkan hasil data responden sebesar 32,5\% menyatakan memiliki kondisi gigi yang sama dengan orang tua. Seperti yang telah diketahui, herediter menjadi salah satu faktor peyebab maloklusi yang diturunkan oleh orangtua, yaitu neuromuscular system (pola koordinasi neuromuscular dari otot wajah, mulut, dan lidah), gigi (bentuk gigi, ukuran gigi, jumlah gigi, dan lain-lain), dan struktur skeletal dimana pada kelas maloklusi tertentu sebagai contoh maloklusi kelas III memang jelas diturunkan. ${ }^{25}$

Berbeda halnya dengan penelitian oleh Thomaz et al $^{15}$ tahun 2010 yang menyatakan status gizi berhubungan dengan gigi berjejal pada gigi permanen dengan kebiasaan bernafas melalui mulut. Diperkirakan terjadinya gigi berjejal tidak hanya disebabkan oleh status gizi yang rendah saja namun juga terjadi akibat kebiasaan buruk yaitu bernafas melalui mulut. Pada seseorang dengan kebiasaan bernafas melalui mulut terjadi ketidakseimbangan antara gigi, bibir, dan lidah sehingga menyebabkan terjadinya partumbuhan abnormal pada struktur wajah. ${ }^{26} \mathrm{Hal}$ ini selaras dengan penelitian oleh Feroza et $\mathrm{al}^{5}$ tahun 2017 di Banjarbaru, sampel sejumlah 60 orang memiliki kebiasaan bernafas melalui mulut paling banyak terjadi maloklusi berat yaitu sebesar $80 \%$. Penelitian longitudinal oleh Moimaz et $\mathrm{al}^{27}$ tahun 2014 juga menyatakan bahwa meningkatnya kejadian maloklusi disebabkan oleh oral habits seperti bernafas melaluli mulut.

Hasil penelitian lain ditemukan berbeda oleh Dermawan et al $^{13}$ tahun 2016 di Padang, yaitu terdapat hubungan bermakna antara status gizi dengan kesejajaran gigi anterior mandibula. Diperoleh hasil $97,1 \%$ responden yang mengalami malnutrisi (gizi kurang dan gizi berlebih) disertai gigi berjejal dengan nilai $\mathrm{p}=0,000$ melalui analisis continuity correction Chi-square. Hasil yang sejalan ditemukan pada penelitian oleh Oktasafitri ${ }^{17}$ tahun 2014 di Medan. Melalui uji statistik chi-square ditunjukkan adanya hubungan bermakna antara kategori status gizi berdasarkan IMT dengan gigi berjejal $\mathrm{p}=0,001$.
Malnutrisi merupakan keadaan gizi yang tidak seimbang dan berpengaruh terhadap perkembangan hormon salah satunya growth hormone $(\mathrm{GH})$ yaitu hormon pertumbuhan yang berperan dalam partumbuhan dan perkembangan tulang, termasuk tulang rahang. Malnutrisi dapat menyebabkan pengurangan pada panjang dasar tengkorak, tinggi rahang, lebar rahang atas dan rahang bawah, serta tinggi wajah. Sejalan dengan hal tersebut, penelitian oleh Weissman et $\mathrm{al}^{28}$ menunjukkan adanya efek dari malnutrisi terhadap pertumbuhan dan perkembangan tulang fasial serta perkembangan otot-otot tulang. Kurangnya partumbuhan dan perkembangan sistem tulang-otot termasuk pada rahang atas dan rahang bawah, menyebabkan ruang untuk erupsi gigi berkurang sehingga terjadi malposisi gigi dalam lengkung gigi. ${ }^{12,28}$

Ketidakseimbangan gizi dapat terjadi sejak masa kanak-kanak, Jika hal tersebut berlangsung lama, maka akan terjadi malnutrisi kronis yang dapat mengganggu proses tumbuh kembang. Erupsi gigi permanen yang terlambat menjadi salah satu manifesttasi dari kekurangan gizi kronis. Penelitian longitudinal oleh Dimaisib-Nabuab et $\mathrm{al}^{29}$ tahun 2018 dengan metode cohort dan follow-up selama 2 tahun, melibatkan 570 anak (86 stunting) menyatakan terdapat hubungan antara gizi dengan pertumbuhan gigi permanen. Berat badan yang kurang dapat memengaruhi terjadinya keterlambatan erupsi gigi permanen. ${ }^{29}$ Selanjutnya keterlambatan erupsi pada gigi permanen dapat memengaruhi gigi geligi yang berada di dekatnya, karena gigi tersebut akan bergerak untuk mengisi ruang yang kosong sehingga dapat menyebabkan gigi permanen akan erupsi pada tempat yang salah dan menyebabkan gigi berjejal. ${ }^{22}$

Asupan gizi yang sesuai sangat dibutuhkan untuk pemenuhan nutrisi yang menjadi kebutuhan utama dalam proses tumbuh kembang secara optimal terutama dalam pembentukan struktur gigi yang sehat dan sempurna. Berbagai zat gizi berperan penting dalam proses pembentukan dan perkembangan gigi baik gigi susu maupun gigi tetap. Kekurangan satu atau lebih zat 
gizi dapat berakibat ketidak sempurnaannya pembentukan dan perkembangan gigi. Kekurangan protein atau yang biasa disebut defisiensi protein juga dapat memengaruhi dimensi panjang mandibula yang dapat menyebabkan gigi berjejal atau maloklusi. ${ }^{30}$

Susu merupakan sumber kalsium yang baik, mudah didapatkan dan sangat diperlukan untuk pertumbuhan dan perkembangan tulang. Kalsium bersama dengan fosfor berfungsi membentuk matrik tulang dan gigi. Berdasarkan penelitian Oktasafitri, ${ }^{17}$ diperoleh sebanyak $67,5 \%$ responden memiliki kebiasaan minum susu, namun tidak didapatkan hubungan bermakna antara kebiasaan minum susu dengan kategori IMT $(\mathrm{p}=0,339>0,05)$. Hal ini mungkin disebabkan adanya faktor lain yang memengaruhi kategori IMT dan tidak hanya berdasarkan faktor kebiasaan minum susu saja. ${ }^{17,31}$

Keadaan status gizi seseorang juga dipengaruhi oleh banyak faktor, salah satunya faktor sosial-ekonomi. Hasil penelitian Thomaz et al $^{15}$ menyatakan bahwa faktor sosial ekonomi seperti pendapatan orang tua dapat memengaruhi status gizi seseorang. Hasil penelitian tersebut memungkinkan mendapat validitas yang bermakna dikarenakan total sampel yang ada sebanyak 2.060 orang. Namun, hasil berbeda ditemukan pada penelitian Oktasafitri ${ }^{17}$ yang menyebutkan tidak adanya hubungan antara pendapatan orang tua dengan status gizi. Oleh karena beragamnya faktor status gizi yang ada maka perlu diteliti faktor penyebab status gizi lainnya yang dapat memengaruhi terjadinya maloklusi.

Keterbatasan penelitian ini dikarenakan literatur yang dikaji memiliki jumlah terbatas dan hanya ditemukan satu jenis penelitian cross-sectional. Selain itu, penggunaan indeks $\mathrm{TB} / \mathrm{U}$ sebagai salah satu penilaian status gizi di masa lampau juga kurang ditemukan dalam penelitian ini. Sebaliknya, penggunaan IMT lebih banyak dipakai sehingga hasil pengukuran yang didapatkan merupakan status gizi di masa sekarang.

\section{SIMPULAN}

Berdasarkan hasil penelitian literatur yang didapatkan, gigi berjejal yang terjadi pada remaja tidak hanya dipengaruhi oleh status gizi saja namun dapat disebabkan oleh faktor lain seperti kebiasaan buruk, riwayat gigi desidui berjejal, keturunan hingga status sosial ekonomi orang tua.

\section{Konflik Kepentingan}

Penulis menyatakan tidak terdapat konflik kepentingan dalam studi ini.

\section{DAFTAR PUSTAKA}

1. Wagiran DIL, Kaunang WPJ, Wowor VNS. Kualitas hidup remaja SMA Negeri 6 Manado yang mengalami maloklusi. Jurnal Kedokteran Komunitas dan Tropik. 2014;2(2):85.

2. Bhalajhi SI. Orthodontics the art and science (3rd ed). New Delhi: Arya Publishing House, 2006; p. 66.

3. Das UM, Venkatsubramanian, Reddy D. Prevalence of malocclusion among school children in Bangalore, India. Int J Clin Pediatr Dent. 2008;1(1):10-2.

4. Wijanarko AG. Prevalensi maloklusi pada remaja usia 12-14 tahun pada Sekolah Menengah Pertama di Jakarta. Jakarta. 1999. Available from: http://lontar.ui.ac. id/opac/themes/libri2/detail.jsp?id=758 06\&lokasi=lokal

5. Feroza NA, Kurniawan FKD, Wibowo D. Hubungan antara kebiasaan buruk bernafas melalui mulut dan tingkat keparahan maloklusi di SMPN 4 Banjar Baru dan SMAN 4 Banjar Baru. Dentino. 2017;II(1):39-41.

6. Abror MIM. Perbedaan indeks DMF-T dan OHI-S pada anak dengan susunan gigi berjejal, normal dan diastema di Sekolah Menengah Pertama Negeri 3 Dempet Demak [Tesis]. Semarang: Universitas Muhammadiyah; 2017.

7. Aini S. Hubungan tingkat kebutuhan perawatan orthodonti dengan minat menggunakan alat orthodonti pada anak gigi berjejal SMP Taman Dewasa [Skripsi Tesis]. Yogyakarta: Poltekkes Kemenkes Yogyakarta; 2015.

8. Freinademetz F. Pengaruh kecerdasan spiritual dan kontrol diri bagi kaum remaja [Skripsi]. Kupang: Unika Widya Mandira; 2018.

9. Mauli JT. Studi deskriptif mengenai kualitas hidup yang terkait dengan kesehatan mulut pada remaja usia 11-14 Tahun 
yang melakukan perawatan ortodontik cekat di SMP "X" Bandung [Tesis]. Bandung: Universitas Kristen Maranatha; 2016.

10. Badan Peneliti dan Pengembangan Kesehatan. Riset Kesehatan Dasar 2010. Jakarta: Departemen Kesehatan RI, 2010; p. 6.

11. Lailasari D, Zenab Y, Herawati E, Wahyuni IS. Correlation between permanent teeth eruption and nutrition status of 6-7years-old children. Padjadjaran J Dent. 2018;30(2):121.

12. Thomaz EBAF, Valenca AMG. Relationship between childhood underweight and dental crowding in decidous theething. $\mathrm{J}$ de Pediatria. 2009;85(2):110-5.

13. Dermawan $\mathrm{CH}$, Aida F, Alioes Y. Hubungan status gizi terhadap kesejajaran gigi anterior mandibula berdasarkan pengukuran Little's irregularity index pada siswa SMPN 5 Padang. Cakradonya Dental J. 2016;9(1):50-2.

14. Erliera, Alamsyah RM. Hubungan status gizi dengan kasus gigi berjejal pada murid SMP Kecamatan Medan Baru. Dentika. 2015;18(3):242-4.

15. Thomaz EBAF, Cangussu MCT, Silva AA, Assis AMO. Is malnutrition associated with crowding in permanent dentition? Int J Environ. 2010;7:3531-6.

16. Jufri PDW, Puspitasari Y, Ilmianti. Hubungan status gizi dengan tingkat keparahan maloklusi pada pelajar usia 14-15 tahun. Sinnun Maxillofacial J. 2019;1(1).

17. Oktasafitri D. Hubungan status gizi dengan gigi berjejal pada murid SMP Sutomo 2 Medan [Skripsi]. Medan: Universitas Sumatera Utara; 2014.

18. Pristarani WN. Hubungan indeks massa tubuh dengan maloklusi menggunakan dental aesthetics index (DAI) [Skripsi]. Yogyakarta: Universitas Muhammadiyah; 2017.

19. Wibawa EP. Hubungan indeks massa tubuh dengan maloklusi menggunakan handicapping malocclusion assessment index (HMAI) [Skripsi]. Yogyakarta: Universitas Muhamadiyah; 2017.

20. Falasifah F. Hubungan indeks massa tubuh dengan maloklusi menggunakan occlusion features index (OFI) [Skripsi]. Yogyakarta: Universitas Muhammadiyah; 2017.
21. Tak M, Nagarajappa R, Sharda AJ, Asawa K, Tak A, Jalihal S. Prevalence of malocclusion and orthodontic treatment needs among 12-15 years old school children of Udaipur, India. Eur J Dent. 2013;7(1):47-8.

22. Graber LW, Vanarsdall RL, Vig KW, Huang GJ. Orthodontics-ebook: Current Principles and Techniques (6th ed). Elsevier Health Sciences, 2016; p. 31.

23. Poosti M, Jalali T. Tooth size and arch dimension in uncrowded versus crowded class I malocclusions. J Contemp Dent Pract. 2007;8(3):45-52.

24. Vinay S, Keshav V, Sankalecha S. Prevalence of spaced and closed dentition and its relation to malocclusion in primary and permanent dentition. Int $\mathbf{J}$ Pediatric Dentistry. 2012;5(2):98.

25. Singh G. Textbook of Orthodontics (2nd ed). New Delhi: Jaypee, 2007; p. 175-89.

26. Becker HMG, Pinto JA. Prevalence of malocclusion among mouth breathing children: do expectation meet reality. Int J Pediatr Otorhinolaryngol. 2009: 73(5): 767.

27. Moimaz SAS, Garbin AJI, Lima AMC, Lolli LF, Saliba O, Garbin CAAS. Longitudinal study of habits leading to malocclusion development in childhood. BMC Oral Health. 2014;14(96). Doi: https://doi.org/10.1186/14726831-14-96

28. Weissman S, Sadowsky PL, Jacobson A, Alvarez JO, Caceda J. Craniofacial growth and development in nutritionally compromised Peruvian Children. J Dent Res. 1993;72:366.

29. Dimaisib-Nabuab J, Duijster D, Benzian H, Heinrich-Weltzien R, Homsavath A, Monse B, et al. Nutritional status, dental caries, and tooth eruption in children: a longitudinal study in Cambodia, Indonesia, and Lao PDR. BMC Pediatr. 2018;18(300):1-12.

30. Gondivkar SM, Gadbail AR, Gondivkar RS, Sarode SC, Sarode GS, Patil S, Awan KH. Nutrition and oral health. Dis Mon. 2019;65(6):147-54.

31. Hardinsyah, Damayanthi E, Zulianti W. Hubungan konsumsi susu dan kalsium dengan densitas tulang dan tinggi badan remaja. J Gizi dan Pangan. 2008; 3(1):43. 